\title{
Purification and characterization of manganese peroxidases from native and mutant Trametes versicolor IBL-04
}

\author{
Muhammad Asgher, Muhammad Ramzan, Muhammad Bilal* \\ Industrial Biotechnology Laboratory, Department of Biochemistry, University of Agriculture, Faisalabad, Pakistan
}

\section{A R T I C L E I N F O}

Article history:

Received 8 November 2015

Accepted 14 January 2016

Published 5 April 2016

\section{Keywords:}

Manganese peroxidase

Trametes versicolor IBL-04

Purification

Characterization

Thermo-stability

Biodegradation

\begin{abstract}
A B S T R A C T
Extracellular manganese peroxidases (MnPs) produced by native and mutant strains of Trametes versicolor IBL-04 (EB-60, EMS-90) were purified by ammonium sulphate precipitation and dialysis, followed by ion-exchange and gel-permeation chromatography. The purified enzymes elucidated a single band in the 43-kDa region on sodium dodecyl sulphate-polyacrylamide gel electrophoresis. The optimum $\mathrm{pH}$ and temperature of the purified enzymes were found to be 5.0 and $40{ }^{\circ} \mathrm{C}$, respectively. Mutant strain MnPs exhibited a broader active $\mathrm{pH}$ range and higher thermal stability than native MnP. Purified MnPs from selected mutants showed almost identical properties to native MnP in electrophoresis, steady-state kinetics, and metal ion and endocrine-disrupting compound (EDC) degradation efficiency. Although the fastest reaction rates occurred with $\mathrm{Mn}^{2+}$, MnPs displayed the highest affinity for ABTS, methoxyhydroquinone, 4-aminophenol and reactive dyes. $\mathrm{MnP}$ activity was significantly enhanced by $\mathrm{Mn}^{2+}$ and $\mathrm{Cu}^{2+}$, and inhibited in the presence of $\mathrm{Zn}^{2+}, \mathrm{Fe}^{2+}$, ethylenediaminetetraacetic acid and cysteine to various extents, with $\mathrm{Hg}^{2+}$ as the most potent inhibitory agent. MnPs from all sources efficiently catalyzed the degradation of the EDCs, nonylphenol and triclosan, removing over $80 \%$ after $3 \mathrm{~h}$ of treatment, which was further increased up to $90 \%$ in the presence of MnP-mediator system. The properties of T. versicolor MnPs, such as high $\mathrm{pH}$ and thermal stability, as well as unique Michaelis-Menten kinetic parameters and high EDC elimination efficiency, render them promising candidates for industrial exploitation.
\end{abstract}

(C) 2016, Dalian Institute of Chemical Physics, Chinese Academy of Sciences. Published by Elsevier B.V. All rights reserved.

\section{Introduction}

Enzymes are efficient and safe biocatalysts with outstanding potential for different industrial processes that require high activity, selectivity and specificity under mild environmental conditions [1-6]. Manganese-dependent peroxidases (MnPs; EC 1.11.1.13) exhibit significant prospects for biotechnological applications, including lignocellulose de-polymerization [7], polymer synthesis [8], bio-bleaching of paper pulp [9], decolorization of textile dyes [10], bio-sensing [11], green chemistry [12], and bio-transformation and detoxification of environmentally persistent aromatics [13]. However, because indige- nous strains of white-rot fungi (WRF) have a long fermentation period, low productivity and poor enzymatic stability, they are inefficient for commercial purposes $[12,14]$. Strain improvement through mutagenesis is considered to be a reliable, short-term and highly developed technique, which incorporates the latest advances from a wide range of scientific and technical disciplines [12,15].

Studies on the isolation and purification of MnPs, and their specific properties, enable evaluation of their suitability for industrial uses, which represents $80 \%$ to $90 \%$ of the total production costs. Industrial processes require enzymes with high resistance to many physico-chemical environmental factors,

* Corresponding author. Tel: +92-41-9200161/3312; E-mail: bilaluaf@hotmail.com 
including $\mathrm{pH}$, temperature and metal ions, accompanied by a high catalytic potential [16]. Furthermore, the development of simplified but viable purification strategies has gained remarkable interest in modern enzyme biotechnology [17-19]. Because enzymes are produced in conjunction with various proteins, some of which have undesired catalytic activity, final volumetric activity may be negatively affected. In addition, contaminant proteins/enzymes with opposing catalytic activity may decrease the enantio- and/or regio-selectivity or specificity of the biocatalyst [6].

Bio-remediation, including wastewater treatment, is a field that uses the metabolic potential and enzymatic systems of WRF to clean the environment [20]. Over the last decades, the emergence of potentially toxic pollutants, known as endocrine-disrupting compounds (EDCs), has been identified and monitored in different water sources. Nonylphenol (NP), a non-ionic surfactant bio-degradation metabolite, and triclosan (TCS), an antibacterial agent, are the two most common EDCs [16] that cause feminization and carcinogenesis in living organisms [21]. Owing to their high tolerance to toxic substances, several approaches employing fungal ligninolytic enzymes have garnered interest for the mineralization of these EDCs [22]. This study aimed to isolate and purify a highly active MnP enzyme from native and mutant strains of Trametes versicolor, and to conduct biochemical characterization. The biotechnological potential for degradation of the EDCs NP and TCS was also assessed.

\section{Experimental}

All chemicals and reagents were of high-grade purity and used as received. Sugarcane bagasse was procured from a local fruit market in Faisalabad, Pakistan. The collected substrate was oven-dried at $60{ }^{\circ} \mathrm{C}$, crushed in a commercial mill (Ashraf Herbal Laboratories limited, Faisalabad, Pakistan) and sieved to 40 -mesh particle size.

\subsection{Organism, culture conditions and inoculum development}

Locally isolated culture of Tremetes versicolor IBL-04 (available in the culture stock at IBL-UAF) was refreshed and multiplied by transfer onto freshly prepared potato dextrose agar (PDA) slants at $28 \pm 2{ }^{\circ} \mathrm{C}, \mathrm{pH}=4.5$ for 6 to $8 \mathrm{~d}$, and then stored at $4{ }^{\circ} \mathrm{C}$. Inoculum was developed by growing the fungus in separately labeled triplicate Erlenmeyer flasks (500 mL) containing Kirk's basal nutrient medium [23] with the following composition (in g/L): glucose, 10.0; ammonium tartrate, $0.2 ; \mathrm{KH}_{2} \mathrm{PO}_{4}, 0.21 ; \mathrm{MgSO}_{4} \cdot 7 \mathrm{H}_{2} \mathrm{O}, 0.05 ; \mathrm{CaCl}_{2}, 0.01$; thiamine, 0.001 ; Tween 80 (10\%), $10 \mathrm{~mL} ; 100 \mathrm{mmol} / \mathrm{L}$ veratryl alcohol, $10 \mathrm{~mL}$; and $10 \mathrm{~mL}$ trace mineral solution. Before sterilization, the medium was adjusted to $\mathrm{pH}=4.5$ using $M(\mathrm{HCl}) / M(\mathrm{NaOH})$. The sterilized medium was supplemented with $1 \%$ Millipore-filtered sterile glucose solution. A loop with T. versicolor culture from the PDA slants was aseptically transferred to the sterile basal medium and incubated (Sanyo Gallenkemp, UK) at $30{ }^{\circ} \mathrm{C}$ for 5 to $7 \mathrm{~d}$. The number of spores was counted with a hemocytometer, and the suspension was adjusted to a spore concentration of $1 \times\left(10^{7}-10^{8}\right) / \mathrm{mL}$ for use as the inoculum [12].

\subsection{Chemical mutagenesis}

\subsubsection{Ethidium bromide (EB)}

A stock solution containing $1.0 \mathrm{mg} / \mathrm{mL}$ of $\mathrm{EB}$ was used to create four further dilutions $(25,50,75$ and $100 \mu \mathrm{g} / \mathrm{mL})$. In a vial, $1.0 \mathrm{~mL}$ of EB solution was added to $9.0 \mathrm{~mL}$ of Vogel's medium containing T. versicolor spores $\left(1 \times 10^{7}\right.$ spores $\left./ \mathrm{mL}\right)$. After pre-designated EB treatment intervals $(30,60,90,120$ and 150 $\min$ ), spores were harvested by washing three times with sterile biological saline solution $(0.89 \% \mathrm{NaCl}$ and $0.1 \%$ yeast extract), followed by centrifugation at $12000 \mathrm{r} / \mathrm{min}$ for $15 \mathrm{~min}$. The mutant spores were spread on agar plates at $30{ }^{\circ} \mathrm{C}$ for colony formation.

\subsubsection{Ethyl methanesulfonate (EMS)}

A stock solution of $500 \mu \mathrm{g} / \mathrm{mL}(\mathrm{v} / \mathrm{v})$ was used to prepare different EMS concentrations to treat fungal spores. After specific time intervals $(30,60,90,120$ and $150 \mathrm{~min})$, the EMS-treated spores were washed, centrifuged $(12000 \mathrm{r} / \mathrm{min}$ for $15 \mathrm{~min}$ ) and plated on nutrient agar plates to give 30 colonies or less per plate.

\subsubsection{Selection and evaluation of mutants}

To identify potentially high yield mutants, the selective marker 2-deoxy-D-glucose was used [15]. Spores exhibiting the best growth in the presence of 2-deoxy-D-glucose were designated as mutant and selected. Five colonies in each case were picked from the plates and subsequently tested for MnP production.

\subsection{MnP production}

MnP was produced in cotton-plugged triplicate shake flasks containing $5.0 \mathrm{~g}$ sugarcane bagasse substrate pre-moistened with Kirk's basal salts solution (60\% moisture $(w / w))$. After sterilization $\left(121{ }^{\circ} \mathrm{C}\right.$ for $15 \mathrm{~min}$ at $\left.15 \mathrm{psi}\right)$, the flasks were inoculated with $5 \mathrm{~mL}$ of homogenized $T$. versicolor spore suspension and left undisturbed in an incubator (Sanyo, Japan) at $30{ }^{\circ} \mathrm{C}$ for $5 \mathrm{~d}$. After fermentation, the spores were harvested by adding $100 \mathrm{~mL}$ of Na-malonate buffer ( $\mathrm{pH}=4.5)$, shaking (120 $\mathrm{r} / \mathrm{min}$ for $30 \mathrm{~min}$ ), and filtration through Whatman filter paper. The filtrates were centrifuged at $12000 \mathrm{r} / \mathrm{min}$ for $10 \mathrm{~min}$, and the supernatants were analyzed for MnP activity [10].

\subsection{MnP activity assay and protein estimation}

After selection of the mutant strains, MnP activity was analyzed, as described previously [24). A typical assay mixture comprised $\mathrm{MnSO}_{4}(1 \mathrm{~mL} ; 1 \mathrm{mmol} / \mathrm{L}), 1 \mathrm{~mL}$ of $50 \mathrm{mmol} / \mathrm{L}$ Na-malonate buffer at $\mathrm{pH}=4.5,500 \mu \mathrm{L}$ of $\mathrm{H}_{2} \mathrm{O}_{2}$ at $25^{\circ} \mathrm{C}$, with $100 \mu \mathrm{L}$ aliquots of appropriately diluted culture supernatant or purified enzyme. Oxidation of $\mathrm{Mn}^{2+}$ to $\mathrm{Mn}^{3+}$ was monitored by spectrophotometry (HALO DB 20) according to the increase in absorbance at $238\left(\varepsilon=6.5 \times 10^{3} \mathrm{~mol}^{-1} \mathrm{~L} \mathrm{~cm}^{-1}\right)$. Enzyme activity 
was expressed as international units (IU). One unit corresponds to the amount of enzyme, which oxidizes $1 \mu \mathrm{mol} / \mathrm{L} \mathrm{Mn}^{2+}$ to $\mathrm{Mn}^{3+}$ per min (at $\mathrm{pH}=4.5$ and $25^{\circ} \mathrm{C}$ ). The control cuvette comprised $100 \mu \mathrm{L}$ of distilled water, instead of enzyme extract. Total protein contents were determined by the Bradford protein assay using bovine serum albumin (BSA) as a calibration standard.

\subsection{MnP Purification}

Briefly, crude MnP extracts obtained from 5-d cultures of native and selected mutant strains of $T$. versicolor IBL-04 were centrifuged at $3000 \mathrm{r} / \mathrm{min}$ for $15 \mathrm{~min}$ to increase clarity using an Eppendorf centrifuge machine (Centrifuge 5415 C, Germany). The cell-free supernatant was saturated (up to 35\%) by gradual addition of ammonium sulphate and stored overnight at $4{ }^{\circ} \mathrm{C}$. The resulting precipitate was recovered $(3000 \mathrm{r} / \mathrm{min}$ for $20 \mathrm{~min}$ at $4^{\circ} \mathrm{C}$ ) and the supernatant was saturated by adding ammonium sulfate (up to 65\%), allowed to stand overnight at $4{ }^{\circ} \mathrm{C}$, centrifuged, and then the pellets were dissolved in the minimum volume of $50 \mathrm{mmol} / \mathrm{L} \mathrm{Na-malonate} \mathrm{buffer}(\mathrm{pH}=4.5)$. The solution was dispersed in a dialysis bag and after sealing securely, dialyzed against the same buffer for $72 \mathrm{~h}$ with buffer changes at different intervals for salt removal. The dialysate was submitted to ion-exchange chromatography using a diethylaminoethyl cellulose column. The column was equilibrated with $100 \mathrm{mmol} / \mathrm{L}$ phosphate buffer $(\mathrm{pH}=6.5$ ) for $24 \mathrm{~h}$, and eluted with a 0 to $1.0 \mathrm{~mol} / \mathrm{L}$ linear gradient of $\mathrm{NaCl}$ in 50 $\mathrm{mmol} / \mathrm{L}$ malonate buffer at a flow rate of $0.5 \mathrm{~mL} / \mathrm{min}$. A total of 60 fractions, each $1.5 \mathrm{~mL}$, were collected, and analyzed for enzyme activity and protein content. The MnP active fractions were pooled and loaded onto a Sephadex G-100 column (10 $\mathrm{mm} \times 300 \mathrm{~mm}$ ). A $50 \mathrm{mmol} / \mathrm{L}$ malonate buffer was used for elution at a flow rate of $0.3 \mathrm{~mL} / \mathrm{min}$. Up to 30 positive fractions $(1.0 \mathrm{~mL})$ were collected and absorbance was measured at 280 nm (CE Cecil 7200, Germany). The purified and concentrated enzyme was stored at $-20^{\circ} \mathrm{C}[10]$.

\subsection{Molecular mass determination by SDS-PAGE}

The molecular mass of purified MnPs was estimated by sodium dodecyl sulfate-polyacrylamide gel electrophoresis (SDS-PAGE) after gel staining with Coomassie Brilliant Blue G-250, followed by calibration against broad-range molecular mass standard protein markers ranging from 17 to $170 \mathrm{kDa}$ (Sigma, USA).

\subsection{Effect of $p H$ and temperature on the stability and activity of $\mathrm{MnPs}$}

The effect of $\mathrm{pH}$ on enzyme activity was investigated by exposing purified MnPs from the native and mutated strains to a $\mathrm{pH}$ range of 3.0 to 10.0 . The $\mathrm{pH}$ stability was determined by pre-incubation of the purified MnPs in buffers of $\mathrm{pH}=5.0$ and $\mathrm{pH}=8.0$ at standard assay temperature for $90 \mathrm{~min}$. To examine the effect of temperature on enzyme activity, the purified enzymes were incubated at temperatures ranging from 20 to
$70{ }^{\circ} \mathrm{C}$ using $\mathrm{MnSO}_{4}$ as an assay substrate at optimized $\mathrm{pH}$. Thermo-stability was evaluated at the selected temperatures of 40 and $60{ }^{\circ} \mathrm{C}$ for $210 \mathrm{~min}$. The appropriate controls were maintained wherever required during the above studies.

\subsection{Steady-state kinetics}

Steady-state kinetic constants for all substrates were determined in $100 \mathrm{mmol} / \mathrm{L}$ sodium tartrate buffer at $\mathrm{pH}=3.5$, except for $\mathrm{Mn}^{2+}(\mathrm{pH}=5.0)$, and veratryl alcohol and syringol $(\mathrm{pH}=3.0)$. Each substrate was individually added to the assay mixture and enzymatic activities were calculated from the molar absorbance of the reaction products of 2,6-dimethoxyhydroquinone $\left(\varepsilon_{397}=562\right)$, veratryl alcohol $\left(\varepsilon_{310}=9300\right)$, ABTS $\left(\varepsilon_{420}=36000\right)$, guaiacol (o-methoxyphenol) $(\varepsilon 456=12100)$, 4-methoxyphenol $\left(\varepsilon_{253}=4990\right)$, 4-aminophenol $\left(\varepsilon_{246}=15627\right)$, methoxyhydroquinone $\left(\varepsilon_{360}=1252\right)$, syringol $\left(\varepsilon_{468}=27500\right)$, catechol $(1,2$-benzenediol $)\left(\varepsilon_{238}=6500\right)$ and $\mathrm{Mn}^{2+}\left(\varepsilon_{238}=6500\right)$. In the case of dyes, enzyme activities were monitored from substrate decolorization using the molar absorbance of Reactive Red $C_{4} B L N\left(\varepsilon_{540}=30000\right)$ and Reactive Black CKF $\left(\varepsilon_{598}=\right.$ 50000). Enzyme activities were measured under standard assay conditions and results were used to construct Lineweaver-Burk reciprocal plots (Graph Pad Prism 6 software).

\subsection{Effect of modulators (activators and/or inhibitors)}

The effect of various modulators, including $\mathrm{Mn}^{2+}, \mathrm{Zn}^{2+}, \mathrm{Co}^{2+}$, $\mathrm{Cu}^{2+}, \mathrm{Fe}^{2+}, \mathrm{Hg}^{2+}, \mathrm{K}^{+}$, ethylenediaminetetraacetic acid (EDTA) and cysteine, on enzyme activities were tested at a concentration range of 5 to $20 \mathrm{mmol} / \mathrm{L}$. MnP activity in the absence of modulators was considered to be the control (100\%). Residual activities were determined according to the standard assay protocol described earlier.

\subsection{Enzymatic degradation of NP and TCS}

The enzymatic removal of NP and TCS was performed according to Cabana et al. [25]. The reaction mixture contained EDCs (NP or TCS; 10 ppm), purified MnPs, Na-malonate buffer (50 mmol/L; $\mathrm{pH}=4.5), \mathrm{MnSO}_{4}(50 \mu \mathrm{mol} / \mathrm{L})$, and $0.4 \mathrm{mmol} / \mathrm{L}$ $\mathrm{H}_{2} \mathrm{O}_{2}$. During NP treatment, $0.5 \%$ methanol and $0.075 \%$ Tween-80 were added to the reaction mixture to enhance the solubility of NP. The reaction was performed at $30^{\circ} \mathrm{C}$ with stirring at $150 \mathrm{r} / \mathrm{min}$. For the $\mathrm{MnP}$-mediator system, $0.2 \mathrm{mmol} / \mathrm{L}$ $\mathrm{MnSO}_{4}$ was added to the reaction mixture as MnP treatment. To verify that degradation was specifically caused by enzymatic oxidation, a control reaction was conducted using distilled water instead of enzyme solution. Samples were periodically collected to investigate the remaining enzymatic activities and EDC concentration.

\subsection{Statistics analysis}

All experiments were conducted independently in triplicates, and the data presented are the mean of three replicates along with the standard deviation $( \pm$ SD). Results were sub- 
jected to analysis of variance (ANOVA) using statistical analysis system software (Minitab 15.1, version year 2007). $P$-values $<0.05$ were considered to denote statistically significant differences.

\section{Results and discussion}

\subsection{MnP production by selected mutants}

To obtain mutant strains of T. versicolor IBL-04 displaying more efficient $\mathrm{MnP}$ production, chemical mutagenesis was performed using solid-substrate fermentation with sugarcane bagasse as a growth substrate. Two mutagenic chemicals, EB and EMS, were applied independently at optimized concentrations of 50 and $100 \mu \mathrm{g} / \mathrm{mL}$, respectively, for different time periods [14]. After exposure for $60 \mathrm{~min}$ (EB-60) and $90 \mathrm{~min}$ (EMS-90), MnP activity was increased by $29.6 \%$ and $32.5 \%$, respectively, compared with the parent strain (Fig. 1). The high $\mathrm{MnP}$ production in culture filtrates of mutated strains may be attributed to overexpression of the mnp- 1 gene caused by the chemical mutagens [26].

In general, strain modification for hyper-production of extracellular enzymes using filamentous fungi is achieved by inducing mutagenesis with various agents, including UV light, $\mathrm{N}$-methyl-N-nitro-N nitrosoguanidine (MNNG), nitrous acid $\left(\mathrm{HNO}_{2}\right)$, EB and EMS, applied individually or in combination [27-30]. EB is an aromatic agent that causes frame-shift mutations by intercalating with double-stranded DNA. In contrast, EMS is thought to have both mutagenic and carcinogenic effects, and it causes random point mutations by promoting nucleotide substitution, in particular, guanine alkylation [14].

Several investigators have documented an increase in enzyme production after exposure of fungi to various mutagens at

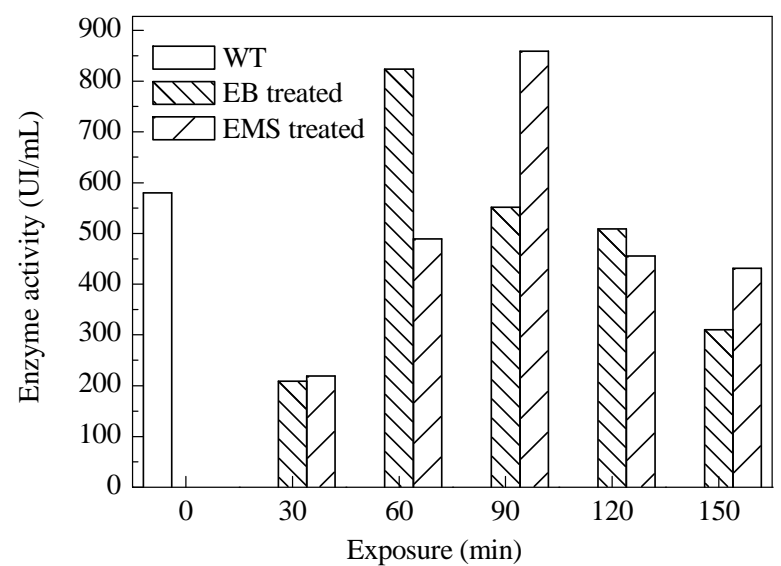

Fig. 1. Production of MnPs by native and mutantstrains of T. versicolor at different exposure time. WT, wild type; EB, Ethidium bromide; EMS, Ethyl methanesulfonate.

sub-lethal concentrations. The effectiveness of the induced mutagenesis depends on the type and concentration of the mutagenic agent, and the duration of exposure [28]. However, treatment of fungi with high concentrations of EB or EMS ( $>100 \mu \mathrm{g} / \mathrm{mL}$ ) reduced $\mathrm{MnP}$ activitiy, probably owing to the detrimental effect of mutagens on cell growth [15]. Similarly, Dhawan et al. [28] also highlighted the lethal effects of high EB concentrations on viability of the WRF Cyathus bulleri. Notably, in the present study, the mutagenic agents primarily caused young and actively growing fungal cells to release higher amounts of MnPs than native cultures of T. versicolor, which displayed much lower MnP activity. Previously, Arunkumar and Abdulla [26] demonstrated that young and metabolically active cells were more susceptible to EB than cells in the stationary phase.

Table 1

Purification of MnP from wild type and mutant strains of T. versicolor IBL-04.

\begin{tabular}{|c|c|c|c|c|c|c|}
\hline Enzyme source & Purification step & $\begin{array}{c}\text { Total protein } \\
\text { (mg) }\end{array}$ & $\begin{array}{c}\text { Total activity a } \\
(\mathrm{UI} / \mathrm{mL})\end{array}$ & $\begin{array}{c}\text { Specific activity }{ }^{\mathrm{b}} \\
\text { (UI/mg) }\end{array}$ & $\begin{array}{l}\text { Purification }{ }^{\mathrm{c}} \\
\text { (fold) }\end{array}$ & $\begin{array}{c}\text { Recovery }^{\mathrm{d}} \\
(\%)\end{array}$ \\
\hline \multirow[t]{5}{*}{ WT strain } & Culture supernatant & 2193 & 580.18 & 132.27 & 1 & 100 \\
\hline & $\left(\mathrm{NH}_{4}\right)_{2} \mathrm{SO}_{4}$ precipitation & 82.3 & 497.23 & 241.67 & 1.83 & 85.70 \\
\hline & Dialysis & 73.4 & 473.01 & 257.77 & 1.95 & 81.53 \\
\hline & DEAE-anion exchange chromatography & 5.58 & 413.42 & 740.98 & 5.60 & 71.26 \\
\hline & Gel permeation chromatography & 1.03 & 164.32 & 957.21 & 7.24 & 28.32 \\
\hline \multirow[t]{5}{*}{ EB-60 strain } & Culture supernatant & 1765.5 & 824 & 140.01 & 1 & 100 \\
\hline & $\left(\mathrm{NH}_{4}\right)_{2} \mathrm{SO}_{4}$ precipitation & 63.6 & 709.13 & 334.5 & 2.39 & 86.06 \\
\hline & Dialysis & 57.4 & 694.17 & 362.01 & 2.59 & 84.24 \\
\hline & DEAE-anion exchange chromatography & 8.7 & 589.23 & 609.55 & 4.35 & 71.51 \\
\hline & Gel permeation chromatography & 0.856 & 317.04 & 1481.49 & 10.58 & 38.48 \\
\hline \multirow[t]{5}{*}{ EMS-90 strain } & Culture supernatant & 1267.36 & 859 & 203.34 & 1 & 100 \\
\hline & $\left(\mathrm{NH}_{4}\right)_{2} \mathrm{SO}_{4}$ precipitation & 43.96 & 773.6 & 387.15 & 1.9 & 90.05 \\
\hline & Dialysis & 39.31 & 759.3 & 405.63 & 1.99 & 88.39 \\
\hline & DEAE-anion exchange chromatography & 4.97 & 534.21 & 1289.84 & 6.34 & 62.19 \\
\hline & Gel permeation chromatography & 1.36 & 293.13 & 1939.83 & 9.54 & 34.12 \\
\hline
\end{tabular}

a UI is defined as the amount of enzyme oxidizing $1 \mu \mathrm{mol}$ of substrate per min.

${ }^{\mathrm{b}}$ Specific activity $=$ UI per mg protein.

c Purification fold $=$ specific activity at given step/specific activity of initial extract.

${ }^{\mathrm{d}}$ Recovery $=($ total activity at given step/total activity of initial extract $) \times 100$. 
The selection of an appropriate plant residue for fungal growth may play a significant role in the development of an efficient technology for enzyme production. Sugarcane bagasse is a major by-product of sugar cane and the alcohol industry. Owing to its high cellulose (50\%), hemicellulose (25\%) and lignin content, sugarcane bagasse offers advantages over other crop residues such as rice straw and wheat straw. Peksen et al. [31] used various substrates for Ganoderma lucidum cultivation, and reported the suitability of rice bran, rice husks, coconut fiber, peanut hulls and sugarcane bagasse as substrates for ligninase production. Similarly, Karp and colleagues [32] reported that sugarcane bagasse was the best substrate for the production and characterization of laccase enzyme by solid-state fermentation of Pleurotus ostreatus.

\subsection{Enzyme purification and gel electrophoresis}

The crude MnP enzyme extracts, which were obtained from parent and mutant strains of T. versicolor IBL-04 (EB-60 and EMS-90) under optimized culture conditions, were purified separately to homogeneity after being subjected to ammonium sulfate fractionation, dialysis, ion-exchange and gel-permeation chromatography. A list of the purified MnPs is provided in Table 1. MnPs from the parent, EB-60 and EMS-90 strains were optimally salted-out with $60 \%$ ammonium sulfate precipitation to achieve 1.95-, 2.59- and 1.99-fold purification, respectively, after dialysis. The de-salted enzyme extracts were first applied to ion-exchange chromatography. The fractions showing high $\mathrm{MnP}$ activity were pooled, concentrated, and further purified by gel-permeation chromatography using a Sephadex G-100 column. After the final purification step, the MnPs were between 7.24- and 10.58-fold purified, with the recovery yield ranging from $28 \%$ to $39 \%$. A variety of MnPs from different fungal cultures have been purified using the ammonium sulphate fractionation method followed by multiple column chromatographic steps [10,33-36]. The specific activity (UI/mg), recovery (\%) and fold-purification of the MnPs in this study are compared with those of previously reported fungal sources in Table 2.

The purified enzyme from the native and selected mutant strains elucidated a single band on SDS-PAGE with an estimated molecular mass of $43.0 \pm 1.5 \mathrm{kDa}$ (Fig. 2). Molecular masses of fungal MnPs usually range from 32.0 to $75.0 \mathrm{kDa}$ [37-42]. The molecular mass of the T. versicolor MnPs isolated in this study was similar to that reported previously for other WRF $[10,43]$.

\subsection{Enzyme characterization}

\subsubsection{Effect of $\mathrm{pH}$ on the activity and stability of the purified $\mathrm{MnPs}$}

Both $\mathrm{pH}$ and temperature play an important role in determining the activity and stability of enzymes. MnP activity was studied at varying pH values (from 3.0 to 9.0) using buffers. The optimum $\mathrm{pH}$ of the purified MnPs secreted by native and mutant strains of T. versicolor was 5.0 (Fig. 3(a)). Further increases in $\mathrm{pH}$ caused a rapid decrease in activity, indicative of enzy-
Table 2

Comparison of specific activity, recovery and purification factor achieved after the last purification step.

\begin{tabular}{|c|c|c|c|c|}
\hline Organism & $\begin{array}{c}\text { Specific activity } \\
\text { (UI/mg) }\end{array}$ & $\begin{array}{c}\text { Recovery } \\
(\%)\end{array}$ & $\begin{array}{l}\text { Purification } \\
\text { fold (\%) }\end{array}$ & Ref. \\
\hline Phanerochaete crassa & 260.7 & 28.9 & 432 & [38] \\
\hline Irpex lacteus & 4.2 & 24.3 & 11 & [39] \\
\hline Schizophyllum sp. F17 & 9.2 & 3.8 & - & {$[52]$} \\
\hline B. pumilus & 31.36 & 802.23 & 5.84 & {$[42]$} \\
\hline Paenibacillus sp. & 8.45 & 685.71 & 1.28 & - \\
\hline Tremetes versicolor & 660 & 3.4 & 2.4 & {$[43]$} \\
\hline Pleurotus ostreatus & 297.34 & - & 3.07 & {$[35]$} \\
\hline Pleurotus ostreatus & 318 & - & 3.22 & {$[44]$} \\
\hline Bjerkandera sp. & 32.3 & 40.2 & 2.4 & {$[53]$} \\
\hline $\begin{array}{l}\text { Phanerochaete } \\
\text { chrysosporium }\end{array}$ & 33 & 1.1 & 1.2 & - \\
\hline $\begin{array}{l}\text { Physisporinus } \\
\text { rivulosus }\end{array}$ & 86.6 & 6.2 & 6.5 & - \\
\hline Phlebia radiate & 30.8 & 13.8 & 2.8 & - \\
\hline Phlebia sp. Nf b19 & 55.2 & 9.3 & 5.2 & - \\
\hline $\begin{array}{l}\text { Schizophyllum } \\
\text { commune }\end{array}$ & 506 & 22 & 1.8 & [36] \\
\hline Pleurotus ostreatus & 78 & 1.2 & 130 & {$[54]$} \\
\hline Ganoderma lucidum & 539.59 & - & 3.43 & {$[10]$} \\
\hline Tremetes versicolor & 957.21 & 28.32 & 7.24 & $\begin{array}{c}\text { Present } \\
\text { study }\end{array}$ \\
\hline EB-60 & 1481.49 & 38.48 & 10.58 & $\begin{array}{l}\text { Present } \\
\text { study }\end{array}$ \\
\hline EMS-90 & 1939.83 & 34.12 & 9.54 & $\begin{array}{c}\text { Present } \\
\text { study }\end{array}$ \\
\hline
\end{tabular}

matic deactivation at non-optimal $\mathrm{pH}$ values. At $\mathrm{pH}=8.0$, the activity of MnP from the native strain decreased to $47.9 \%$, whereas MnPs from the mutants (EB-60 and EMS-90) retained $73.7 \%$ and $73.2 \%$, respectively, of their maximum activities. Studies on MnPs derived from Irpex lacteus, Phanerochaete crassa WD1694, Pleurtous ostreatus, Ganoderma lucidum and Schizophyllum commune showed that the optimal $\mathrm{pH}$ for fungal MnPs ranges from 4.5 to $6.5[36,41,42]$. Generation of novel MnPs with activity across a wider $\mathrm{pH}$ range than that obtained by chemical mutagenesis is believed to be beneficial for industrial applications.

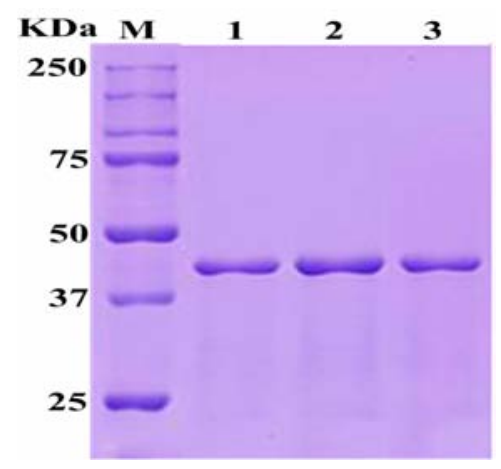

Fig. 2. Electrophoresis of MnPs from T. versicolor IBL-04 stained with Coomassie brilliant blue. Lane M, protein standard marker; Lane 1, MnP from native T. versicolor; Lane 2, MnP from EB-60 strain; Lane 3, MnP from EMS-90 stain. 

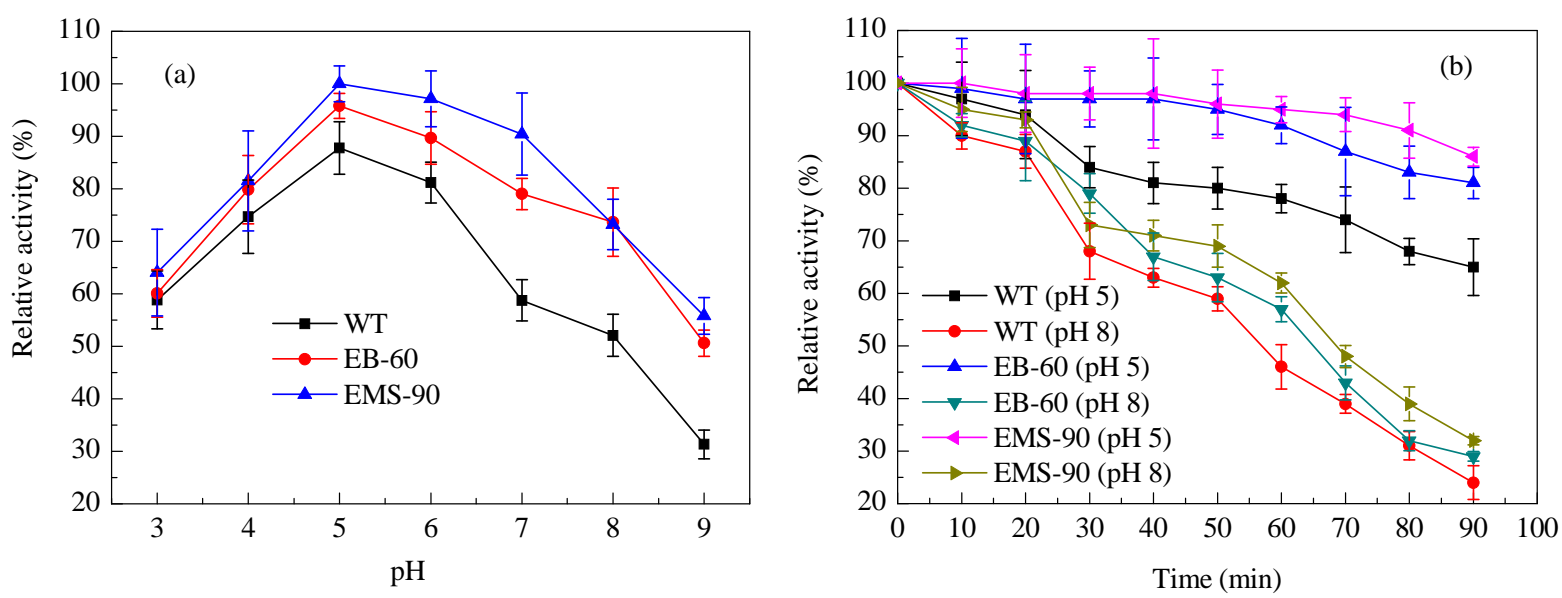

Fig. 3. Effect of pH on MnPs activity (a) and pH stability for MnPs (b).

The $\mathrm{pH}$ stability of the MnPs was studied by incubation at $\mathrm{pH}=5.0$ and $\mathrm{pH}=8.0$ for $90 \mathrm{~min}$, and the results are depicted in Fig. 3(b). At $\mathrm{pH}=5.0$, the MnPs from EB-60 and EMS-90 retained $92 \%$ and $96 \%$, respectively, of their initial activity after $60 \mathrm{~min}$, falling to $81 \%$ and $86 \%$, respectively, after $90 \mathrm{~min}$. In contrast, MnP from the native strain displayed a $22 \%$ and $45 \%$ reduction in activity at $\mathrm{pH}=5.0$ after $60 \mathrm{~min}$ and $90 \mathrm{~min}$, respectively. At $\mathrm{pH}=8.0$, the activity of MnPs from the native, EB-60 and EMS-90 strains declined by $76 \%, 71 \%$ and $68 \%$ respectively, after $90 \mathrm{~min}$. The loss of enzymatic activity observed at a basic $\mathrm{pH}$ may be explained by irreversible denaturation. The majority of purified fungal MnPs exhibit moderate-to-high activity and reasonable stability within the $\mathrm{pH}$ range of 4.0 to $7.0[10,44]$.

\subsubsection{Effect of temperature on the activity and stability of the purified MnPs}

MnPs from both the native and mutant strains had an optimum temperature of $40{ }^{\circ} \mathrm{C}$, with enzyme activity increasing from 25 to $40^{\circ} \mathrm{C}$ and dropping gradually at temperatures above $40{ }^{\circ} \mathrm{C}$ (Fig. 4(a)). MnPs of the native EB-60 and EMS-90 strains of $T$. versicolor retained up to $44 \%, 53 \%$ and $62 \%$ of their respective activities at $60{ }^{\circ} \mathrm{C}$. The EMS-90 mutant MnP displayed the highest activity level over the widest temperature range,

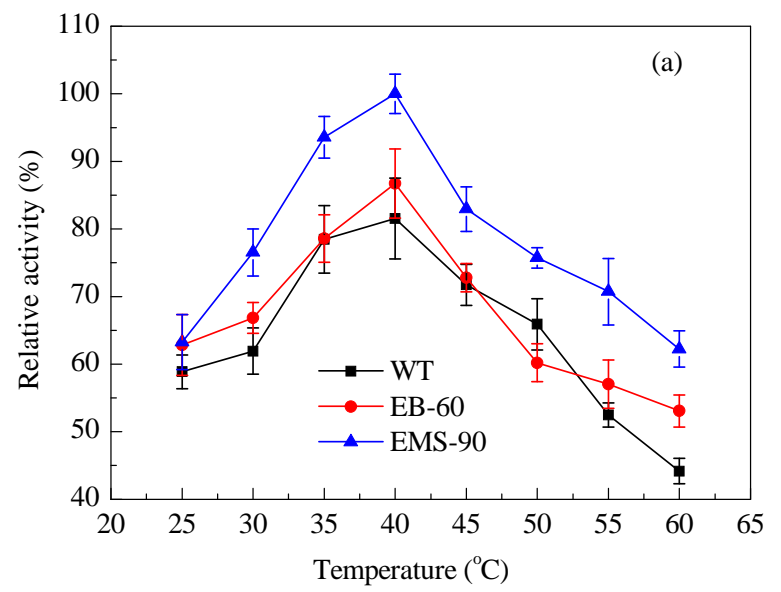

followed by EB-60 and then the parental strain. Most MnPs isolated from different fungal cultures retain their original activities within a temperature range of 30 to $50^{\circ} \mathrm{C}[39,41,45]$.

The stability of the enzymes at different temperatures is shown in Fig. 4(b). Residual enzyme activities were 78\%, 87\% and $89 \%$ for the native, EB-60 and EMS-90 strains of T. versicolor, respectively, after $3 \mathrm{~h}$ at $40{ }^{\circ} \mathrm{C}$. At temperatures above $50{ }^{\circ} \mathrm{C}$, enzyme stability gradually declined. The native strain $\mathrm{MnP}$ lost $50 \%$ of its original activity at $60{ }^{\circ} \mathrm{C}$ after $120 \mathrm{~min}$, whereas the EB-60 and EMS-90 strains retained $62 \%$ and $63 \%$ of their respective activities even after $180 \mathrm{~min}$. Many industrial processes occur at extreme $\mathrm{pH}$ levels (either acidic or alkaline) and high temperatures, making it necessary to identify enzymes with superior thermal stability [46]. Enzymes must also be capable of withstanding harsh conditions for longer processing time. The use of high temperatures $\left(50{ }^{\circ} \mathrm{C}\right.$ and above) has the advantage of reducing microbial contamination of the substrate being processed. Owing to their high thermal tolerance and activity across a wide $\mathrm{pH}$ range, the T. versicolor MnPs represent valuable enzymes to be explored for industrial uses.

\subsubsection{Substrate specificity and kinetic parameters $\left(K_{m}\right.$ and $\left.V_{\max }\right)$}

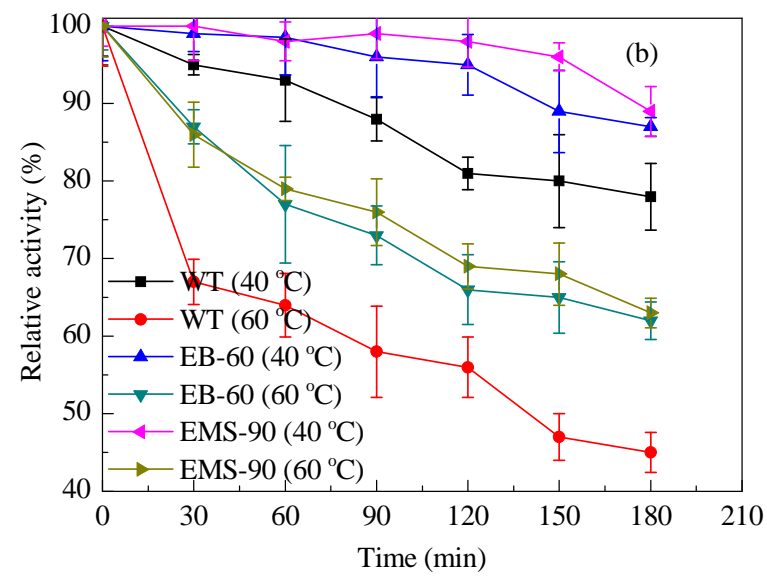

Fig. 4. Effect of temperature on MnPs activity (a) and thermal stability of MnPs from native and mutant strains of T. versicolor (b). 
The steady-state kinetic constants for the oxidation of veratryl alcohol, syringol, $\mathrm{Mn}^{2+}$, reactive dyes, different hydroquinones, substituted phenols and other aromatic compounds by native and mutant $T$. versicolor MnPs were calculated, and the respective apparent $K_{\mathrm{m}}$ and $V_{\max }$ values are listed in Table 3. The substrates, including 2,6-dimethoxyhydroquinone, veratryl alcohol, guaiacol, 4-methoxyphenol, syringol and catechol, displayed apparent $K_{\mathrm{m}}$ values that were greater than those for $\mathrm{Mn}^{2+}$ oxidation, suggesting lower affinity for enzymes. Similar observations regarding the higher affinity of $\mathrm{MnP}$ for $\mathrm{Mn}^{+2}$ have been made previously $[10,35,36]$. Notably, with respect to $\mathrm{Mn}^{2+}$, the MnPs from all sources showed higher affinities for 4-aminophenol, methoxyhydroquinone, ABTS and the reactive dyes tested. Catalytic efficiency $\left(V_{\max } / K_{\mathrm{m}}\right)$ was highest for ABTS and $\mathrm{Mn}^{2+}$, followed by reactive dyes and other hydroquinones. The substrate oxidizing potential by MnPs from native and mutant strains was very similar, revealing that they belong to the same group of class II peroxidases [47].

\subsubsection{Effect of metal ion supplementation on the activity of purified MnPs}

During catalysis, metal ions form complexes with enzymes that either maintain or disrupt the three-dimensional structure and configuration [48]. Therefore, the potential stimulatory or inhibitory effects of various organic compounds and metal ions on the activity of MnPs from the native and mutant strains were investigated (Table 4). The data revealed that $\mathrm{Mn}^{2+}$ and $\mathrm{Cu}^{2+}$ substantially enhanced the activity of MnPs (by $13 \%$ to $53 \%$ ) at all concentrations tested. The metal ion $\mathrm{Mn}^{2+}$ was the most potent inducer of $T$. versicolor $\mathrm{MnP}$, which is in accordance with the findings of Boer et al. [41]. In addition, $\mathrm{Co}^{2+}$ at a low concentration ( $5 \mathrm{mmol} / \mathrm{L}$ ) moderately increased MnP activity, while at a high concentration of $\mathrm{Co}^{2+}(20 \mathrm{mmol} / \mathrm{L})$, slight inhibition (7\% to $10 \%$ ) was observed. Elevated $\mathrm{K}^{+}$concentrations improved MnP activity (117\%), whereas a low concentration (5 mmol/L) did not exert any effect on MnP activity. $\mathrm{Zn}^{2+}$ and $\mathrm{Fe}^{2+}$ had the smallest impact on $\mathrm{MnP}$ activity. In contrast, EDTA and cysteine strongly inhibited MnP activity, and even
Table 4

Effects of various modulators on the activity of purified MnPs from native and mutant $T$. versicolor.

\begin{tabular}{|c|c|c|c|c|}
\hline \multirow{2}{*}{ Modulator } & \multirow{2}{*}{$\begin{array}{c}\text { Concentration } \\
(\mathrm{mmol} / \mathrm{L})\end{array}$} & \multicolumn{3}{|c|}{ Relative activity (\%) } \\
\hline & & WT & EB-60 & EMS-90 \\
\hline \multirow[t]{3}{*}{$\mathrm{Mn}^{2+}$} & 5 & $113 \pm 6.4$ & $118 \pm 2.4$ & $114 \pm 3.5$ \\
\hline & 10 & $137 \pm 5.3$ & $140 \pm 1.9$ & $149 \pm 2.9$ \\
\hline & 20 & $146 \pm 3.7$ & $153 \pm 2.3$ & $145 \pm 2.6$ \\
\hline \multirow[t]{3}{*}{$\mathrm{Zn}^{2+}$} & 5 & $87 \pm 2.8$ & $91 \pm 1.4$ & $89 \pm 2.4$ \\
\hline & 10 & $74 \pm 2.5$ & $74 \pm 1.9$ & $75 \pm 2.6$ \\
\hline & 20 & $56 \pm 4.2$ & $64 \pm 1.3$ & $63 \pm 1.2$ \\
\hline \multirow[t]{3}{*}{$\mathrm{Co}^{2+}$} & 5 & $108 \pm 5.1$ & $117 \pm 4.2$ & $121 \pm 5.6$ \\
\hline & 10 & $104 \pm 4.6$ & $119 \pm 1.7$ & $123 \pm 3.1$ \\
\hline & 20 & $90 \pm 4.7$ & $93 \pm 1.4$ & $91 \pm 3.4$ \\
\hline \multirow[t]{3}{*}{$\mathrm{Cu}^{2+}$} & 5 & $115 \pm 4.5$ & $123 \pm 2.4$ & $114 \pm 4.0$ \\
\hline & 10 & $118 \pm 3.9$ & $124 \pm 3.8$ & $123 \pm 1.1$ \\
\hline & 20 & $129 \pm 4.9$ & $129 \pm 1.2$ & $130 \pm 1.4$ \\
\hline \multirow[t]{3}{*}{$\mathrm{Fe}^{2+}$} & 5 & $83 \pm 1.4$ & $87 \pm 1.8$ & $88 \pm 2.1$ \\
\hline & 10 & $58 \pm 2.4$ & $59 \pm 1.6$ & $63 \pm 1.9$ \\
\hline & 20 & $41 \pm 4.2$ & $49 \pm 1.8$ & $49 \pm 1.3$ \\
\hline \multirow[t]{3}{*}{$\mathrm{Hg}^{2+}$} & 5 & $14 \pm 0.9$ & $19 \pm 0.29$ & $20 \pm 0.41$ \\
\hline & 10 & $7.6 \pm 0.13$ & $10.6 \pm 0.31$ & $10.9 \pm 0.27$ \\
\hline & 20 & $3.3 \pm 0.29$ & $5.3 \pm 0.91$ & $5.1 \pm 0.43$ \\
\hline \multirow[t]{3}{*}{$\mathrm{K}^{2+}$} & 5 & $102 \pm 4.0$ & $101 \pm 3.1$ & $101 \pm 4.8$ \\
\hline & 10 & $108 \pm 3.9$ & $109 \pm 2.2$ & $112 \pm 2.5$ \\
\hline & 20 & $116 \pm 5.3$ & $117 \pm 1.4$ & $121 \pm 2.1$ \\
\hline \multirow[t]{3}{*}{ EDTA } & 5 & $47 \pm 1.9$ & $45 \pm 1.6$ & $51 \pm 2.5$ \\
\hline & 10 & $34 \pm 2.3$ & $39 \pm 1.3$ & $40 \pm 2.1$ \\
\hline & 20 & $28 \pm 2.4$ & $33 \pm 1.4$ & $33.2 \pm 1.6$ \\
\hline \multirow[t]{3}{*}{ Cysteine } & 5 & $33 \pm 1.7$ & $38 \pm 1.2$ & $38.9 \pm 1.3$ \\
\hline & 10 & $21 \pm 2.1$ & $21 \pm 3.5$ & $24 \pm 2.4$ \\
\hline & 20 & $8 \pm 0.73$ & $9 \pm 0.6$ & $14 \pm 0.52$ \\
\hline
\end{tabular}

Data are expressed as the mean \pm SD $(n=3)$.

$\mathrm{Hg}^{2+}$ fully de-activated the MnP enzyme. $\mathrm{Hg}^{2+}$ is highly toxic because it disrupts the tertiary protein structure by oxidizing -SH groups found on cysteine residues [49]. It has a potent inhibitory effect on MnPs from different fungal strains, including Phanerochaete crassa WD1694 [38], Trichophyton rubrum

Table 3

Steady-state kinetics constants for oxidation of different substrates by MnPs from native and mutant T. versicolor.

\begin{tabular}{|c|c|c|c|c|c|c|}
\hline \multirow{2}{*}{ Substrate } & \multicolumn{2}{|c|}{ Tremetes versicolor } & \multicolumn{2}{|c|}{ EB-60 } & \multicolumn{2}{|c|}{ EMS-90 } \\
\hline & $K_{\mathrm{m}}(\mu \mathrm{mol} / \mathrm{L})$ & $V_{\max }(\mathrm{UI} / \mathrm{mg})$ & $K_{\mathrm{m}}(\mu \mathrm{mol} / \mathrm{L})$ & $V_{\max }(\mathrm{UI} / \mathrm{mg})$ & $K_{\mathrm{m}}(\mu \mathrm{mol} / \mathrm{L})$ & $V_{\max }(\mathrm{UI} / \mathrm{mg})$ \\
\hline 2,6-Dimethoxyhydroquinone & $47.0 \pm 1.8$ & $51 \pm 1.7$ & $42 \pm 1.2$ & $59 \pm 2.1$ & $54 \pm 0.7$ & $33 \pm 0.4$ \\
\hline Veratryl alcohol & $2378 \pm 5.6$ & $38 \pm 1.1$ & $2145 \pm 4.7$ & $46 \pm 1.4$ & $2432 \pm 6.3$ & $29 \pm 0.6$ \\
\hline ABTS & $7.0 \pm 0.04$ & $57 \pm 2.6$ & $9.0 \pm 0.06$ & $56 \pm 2.6$ & $14.0 \pm 0.4$ & $62 \pm 1.3$ \\
\hline Guaiacol & $82.0 \pm 1.2$ & $19.0 \pm 0.5$ & $67 \pm 2.5$ & $79 \pm 1.9$ & $68 \pm 0.9$ & $37 \pm 1.2$ \\
\hline 4-Methoxyphenol & $127 \pm 1.7$ & $43 \pm 1.4$ & $143 \pm 3.8$ & $34 \pm 1.1$ & $132 \pm 1.7$ & $47 \pm 2.3$ \\
\hline 4-Aminophenol & $32.0 \pm 0.9$ & $21 \pm 0.8$ & $21.0 \pm 1.2$ & $22 \pm 0.8$ & $32 \pm 0.6$ & $29 \pm 0.3$ \\
\hline Methoxy hydroquinone & $12.0 \pm 0.3$ & $42 \pm 2.1$ & $9.0 \pm 0.2$ & $44 \pm 1.0$ & $10.0 \pm 0.04$ & $28 \pm 0.5$ \\
\hline Syringol & $297 \pm 3.8$ & $22 \pm 1.2$ & $282 \pm 4.2$ & $26 \pm 1.3$ & $300 \pm 3.5$ & $26 \pm 0.4$ \\
\hline Catechol & $123 \pm 2.6$ & $49 \pm 1.3$ & $104 \pm 1.9$ & $38 \pm 1.3$ & $112 \pm 1.4$ & $46 \pm 1.1$ \\
\hline Reactive Red $\mathrm{C}_{4} \mathrm{BLN}$ & $38.0 \pm 0.06$ & $142 \pm 3.3$ & $38.0 \pm 0.04$ & $148 \pm 3.4$ & $41.0 \pm 0.02$ & $149 \pm 1.3$ \\
\hline Reactive Black CKF & $37.0 \pm 0.08$ & $129 \pm 2.1$ & $36.0 \pm 0.06$ & $141 \pm 1.9$ & $34.0 \pm 0.2$ & $142 \pm 2.0$ \\
\hline $\mathrm{Mn}^{2+}$ & $39 \pm 0.8$ & $213 \pm 3.7$ & $37 \pm 1.2$ & $228 \pm 2.7$ & $53 \pm 2.1$ & $252 \pm 3.1$ \\
\hline
\end{tabular}

Data are expressed as the mean \pm SD $(n=3)$. 
LSK-27 [41], Pleurotus ostreatus [35], Schizophyllum commune [36] and Ganoderma lucidum [10]. MnP from P. chrysosporium was inhibited by $\mathrm{NaN}_{3}, \beta$-mercaptoethanol and dithreitol, whereas co-oxidants, including glutathione, un-saturated fatty acids and Tween-80, significantly improved MnP activity [33]. In another study, $\mathrm{Hg}^{2+}$ abolished $\mathrm{MnP}$ activity, while $\mathrm{Fe}^{3+}, \mathrm{Ca}^{2+}$ and $\mathrm{Ni}^{2+}$ did not affect enzyme activity [41].

\subsection{Bio-degradation of NP and TCS by MnP-catalyzed oxidation}

The most common EDCs, NP and TCS, were treated with MnPs from native and mutant strains (EB-60 and EMS-90) of $T$. versicolor IBL- 04 at $\mathrm{pH}=5.0$ and $40{ }^{\circ} \mathrm{C}$. Fig. 5 illustrates the time-course elimination profile of NP and TCS. The removal efficiency of NP was determined to be $45 \%$ and $70 \%$ after 30 min and $1 \mathrm{~h}$ of treatment, respectively. Over $95 \%$ of NP was eliminated from the solution after $3 \mathrm{~h}$ of treatment (Fig. 5(a)). Similarly, the MnP enzyme preparation removed 23\% of TCS from the solution after $30 \mathrm{~min}, 37 \%$ after $60 \mathrm{~min}$, and $82 \%$ after $3 \mathrm{~h}$ (Fig. 5(c)). Further, the ability of the natural mediator $\left(\mathrm{MnSO}_{4} ; 0.2 \mathrm{mmol} / \mathrm{L}\right)$ to improve the bio-degradation of NP and TCS was assessed. Mediators are proposed to broaden the substrate range over MnPs [25]. The remaining efficiency (\%) after $1 \mathrm{~h}$ of mediator treatment is compared in Fig. 5(b) and (d). It was noted that the use of $\mathrm{MnSO}_{4}$ substantially enhanced the elimination efficiency of both toxic chemicals tested $(\alpha=0.05)$.
Using $\mathrm{MnSO}_{4}$, over $90 \%$ removal of both chemicals was achieved after $1 \mathrm{~h}$. However, the mediator alone did not eliminate any NP and TCS.

In a previous study, 8-h treatment of NP and TCS (10 ppm) with purified Pycnoporus sanguineus laccases (Lac I and Lac II) yielded over $90 \%$ degradation efficiency [16]. After $4 \mathrm{~h}$ of treatment, more than $65 \%$ of NP, BPA and TCS (5 ppm) were eliminated [25]. The estrogenic activities of NP and BPA (5 ppm) were completely abolished within $12 \mathrm{~h}$ of treatment with MnP and laccase from Phanerochaete chrysosporium ME-446 and Trametes versicolor IF070473, respectively [50]. In a preliminary experiment, the same research group treated NP and BPA with P. chrysosporium and T. versicolor, demonstrating that the majority of both compounds were mineralized after $7 \mathrm{~d}$. Compared with whole cultures, the ligninolytic enzyme-based technology led to more rapid disappearance of NP and bisphenol A (BPA). In addition, several authors highlighted the efficiencies of ligninolytic enzymes obtained from different fungal cultures, with bio-degradation of NP and TCS (50 ppm) in the range of $60 \%$ to $95 \%$ [51].

\section{Conclusions}

The yield of MnPs from T. versicolor IBL-04 was considerably increased by chemical mutagenesis. Compared with the native strain, the activity of MnPs from two genetically modi-
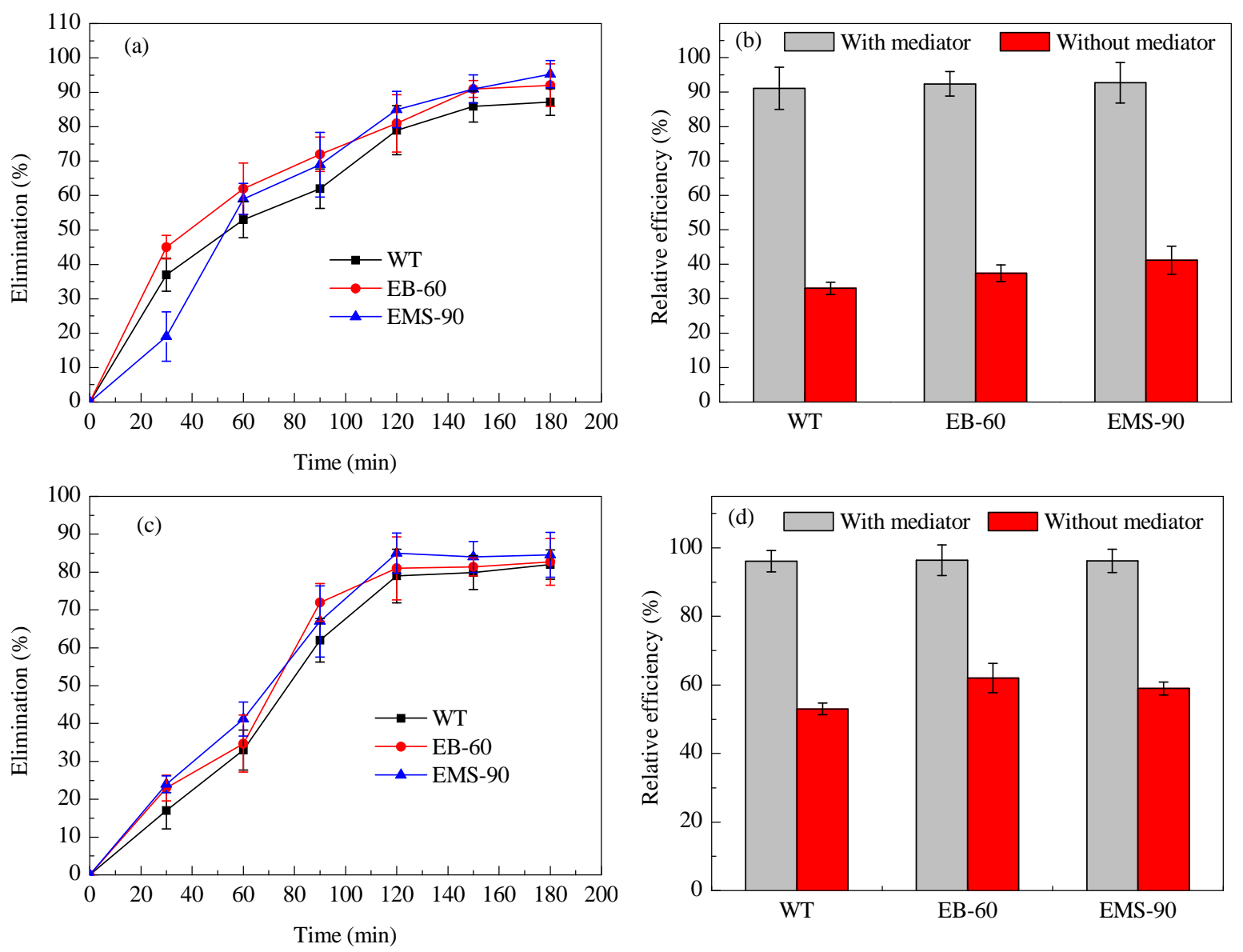

Fig. 5. EDCs bio-degradation by MnPs from native and mutants T. versicolor strains, Elimination profile of NP (a, b) and TCS (c, d). 
fied mutants, EB-60 and EMS-90, was increased by $29.6 \%$ and $32.5 \%$, respectively. The mutant MnPs were tolerant to a wider $\mathrm{pH}$ and temperature range than the native MnP. They showed remarkable potential to eliminate toxic EDCs with good degradation efficiency at $40{ }^{\circ} \mathrm{C}$ in aqueous solution. Immobilization strategies to improve the activity and thermo-stability characteristics of the purified enzymes may be future options for developing economically viable and highly sustainable industrial processes.

\section{Acknowledgments}

The present investigation was a part of a research project entitled "The development of immobilized ligninolytic enzymes for industrial applications" supported by Higher Education Commission (HEC), Islamabad, Pakistan. For providing financial support, HEC is thankfully acknowledged.

\section{References}

[1] C. Garcia-Galan, A. Berenguer-Murcia, R. Fernandez-Lafuente, R. C. Rodrigues, Adv. Synth. Catal., 2011, 353, 2885-2904.

[2] M. T. Reetz, J. Am. Chem. Soc., 2013, 135, 12480-12496.

[3] H. Gröger, W. Hummel, Curr. Opin. Chem. Biol., 2014, 19, 171-179.

[4] C. B. Teixeira, J. V. M. Junior, G. A. Macedo, Renew. Sust. Energ. Rev., 2014, 33, 333-343.

[5] A. Wells, H. P. Meyer, ChemCatChem., 2014, 6, 918-920.

[6] O. Barbosa, C. Ortiz, A. Berenguer-Murcia, R. Torres, R. C. Rodrigues, R. Fernandez-Lafuente, Biotechnol. Adv., 2015, 33, 435-456.

[7] N. Munir, M. Asgher, I. M. Tahir, M. Riaz, M. Bilal, S. M. A. Shah, Int. J. Chem. Biol. Sci., 2015, 7, 9-14.

[8] R. Sanghi, P. Verma, S. Puri, Adv. Chem. Eng. Sci, 2011, 1, 154-162.

[9] D. Moldes, E.M. Cadena, T. Vidal, Bioresour. Technol., 2010, 101, 6924-6929.

[10] M. Bilal, M. Asgher, M. Ramzan, Sci. Res. Enz. Essays., 2015, 10, 456-464.

[11] M. Ardhaoui, S. Bhatt, M. H. Zheng, D. Dowling, C. Jolivalt, F. A. Khonsari, Mater. Sci. Eng. C, 2013, 33, 3197-3205.

[12] Q. Yasmeen, M. Asgher, M. A. Sheikh, H. Nawaz, BioRes., 2013, 8,
944-968.

[13] I. Stoilova, A. Krastanov, V. Stanchev, Adv. Biosci. Biotechnol., 2010, 1, 208-215.

[14] M. Ramzan, M. Asgher, M. A. Sheikh, H. N. Bhatti, BioRes., 2013, 8, 3953-3966.

[15] S. Javed, M. Asgher, M. A. Sheikh, H. Nawaz, Food Biotechnol., 2010, 24, 165-179.

[16] L. I. Ramirez-Cavazos, C. Junghanns, N. Ornelas-Soto, D. L. Cardenas-Chavez, C. Hernandez-Luna, P. Demarche, E. Enaud, R. Garcia-Morales, S. N. Agathos, R. Parra, J. Mol. Catal. B, 2014, 108, 32-42.

[17] S. H. Krishna, N. D. Srinivas, K. S. M. S. Raghavarao, N. G. Karanth, Adv. Biochem. Eng. Biotechnol., 2002, 75, 119-183.

[18] H. B. Costa, S. G. Delboni, F. S. Fortunato, J. A. Ventura, Act. Hort., 2009, 822, 239-244.

[19] N. Jaiswal, V. P. Pandey, U. N. Dwivedi, Int. J. Biol. Macromole., 2015, 72, 326-332.

[20] K. Watanabe, Curr. Opin. Biotechnol, 2001, 12, 237-241.

[21] A. Zgola-Grzeskowiak, T. Grzeskowiak, R. Rydlichowski, Z. Lukaszewski, Chemosphere, 2009, 75, 513-518.

[22] M. Asgher, H. N. Bhatti, M. Ashraf, R. L. Legge, Biodegradation, 2008, 19, 771-783.

[23] M. Tien, T. K. Kirk, Proceed. Nat. Acad. Sci. (USA), 1984, 81, 2280-2284.

[24] H. Wariishi, K. Valli, M. H. Gold, J. Biol. Chem., 1992, 267, 23688-23695.

[25] H. Cabana, J. L. H. Jiwas, R. Rozenberg, V. Elisashvili, M. Penninckx, S. N. Agathos, J. P. Jones, Chemospehere, 2007, 67, 770-778.

[26] M. Arunkumar, S. H. Sheik Abdulla, Desalin. Water Treat., 2015, 56, 509-520.

[27] P. Ellaiah, T. Prabhakar, B. Ramakrishna, A. T. Taleb, K. Adinarayana, Indian J. Microbiol., 2002, 42, 151-153.

[28] S. Dhawan, R. Lal, R. C. Kuhad, Lett. Appl. Microbiol., 2003, 36, 64-67.

[29] S. K. Karanam, N. R. Medicherla, Afr. J. Biotechnol., 2008, 7, 2064-2067.

[30] L. Toscano, V. Gochev, G. Montero, M. Stoytcheva, Biotechnol. Biotechnol. Equip., 2011, 25, 2243-2247.

[31] A. Pekșen, G. Yakupoglu, B. Kibar, Acta Horti., 2009, 830, 319-325.

[32] S. G. Karp, V. Faraco, A. Amore, L. Birolo, C. Giangrande, V. T. Soccol, A. Pandey, C. R. Soccol, Bioresour. Technol., 2012, 114,

\section{Graphical Abstract}

Chin. J. Catal., 2016, 37: 561-570 doi: 10.1016/S1872-2067(15)61044-0

\section{Purification and characterization of manganese peroxidases from native and mutant Trametes versicolor IBL-04}

Muhammad Asgher, Muhammad Ramzan, Muhammad Bilal* University of Agriculture, Pakistan

Manganese peroxidases (MnPs) from native and chemically mutant strains of Trametes versicolor IBL-04 were purified and characterized. The mutant MnPs were active and tolerant over broader $\mathrm{pH}$ and temperature ranges, and exhibited remarkable potential to eliminate toxic EDCs.

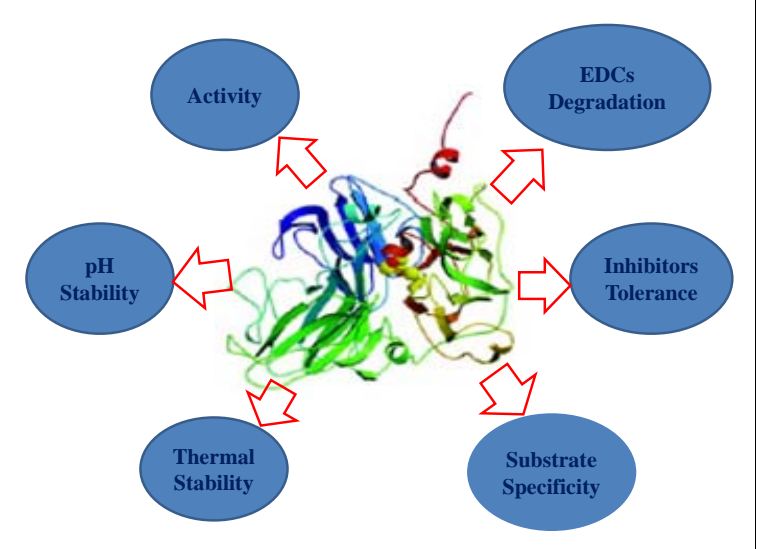


735-739.

[33] R. O. Urek, N. K. Pazarlioglu, Process Biochem., 2004, 39, 2061-2068.

[34] A. Rajan, J. G. Kurup, T. E. Abraham, Braz. Arch. Biol. Technol., 2010, 53, 555-562.

[35] S. Aslam, M. Asgher, Afr. J. Biotechnol., 2011, 10, 17875-17883.

[36] M. Bilal, M. Asgher, BMC Biotechnol., 2015, 15,111-125.

[37] F. Hoshino, T. Kajino, H. Sugiyama, O. Asami, H. Takahashi, FEBS Lett., 2002, 530, 249-252.

[38] T. Mariko, N. Masaya, N. Atsumi, I. Mitsuro, Bull. FFPRI, 2004, 3 , 7-13.

[39] K. S. Shin, Y. H. Kim, J. S. Lim, J. Microbiol., 2005, 43, 503-509.

[40] P. P. Champagne, J. A. Ramsay, Appl. Microbiol. Biotechnol., 2005, 69, 276-285.

[41] C. G. Boer, L. Obici, C. G. M. de Souza, R. M. Peralta, Bioresour. Technol., 2004, 94, 107-112.

[42] P. L. de Oliveira, M. C. T. Duarte, A. N. Ponezi, L. R. Durrant, Braz. J. Microbiol., 2009, 40, 818-826.

[43] M. Asgher, H. M. N. Iqbal, Bio. Res., 2011, 6, 4302-4315.

[44] M. Ferhan, A. L. Leao, I. S. de Melo, N. Yan, M. Sain, Ferment. Tech- nol., 2012, 1(5), doi:10.4172/2167-7972.1000106.

[45] Y. J. Cai, H. G. Wu, X. R. Liao, Y. R. Ding, J. Sun, D. B. Zhang, Biotechnol. Bioprocess Eng., 2010, 15, 1016-1021.

[46] N. Karthik, P. Binod, A. Pandey, Bioresour. Technol., 2015, 188, 195-201.

[47] A. Heinfling, M.J. Martinez, A.T. Martinez, M. Bergbauer, U. Szewzyk, Appl. Environ. Microbiol., 1998, 64, 2788-2793.

[48] C. Andreini, I. Bertini, G. Cavallaro, G. L. Holliday, J. M. Thornton, J. Biol. Inorg. Chem., 2008, 13, 1205-1218.

[49] M. Bilal, M. Asgher, Chem. Cent. J., 2015, 9, 47, doi: 10.1186/s13065-015-0125-0.

[50] Y. Tsutsumi, T. Haneda, T. Nishida, Chemosphere, 2001, 42, 271-276.

[51] T. Saito, K. Kato, Y. Yokogawa, M. Nishida, N. Yamashita, J. Biosci. Bioengineer., 2004, 98, 64-66.

[52] X. B. Cheng, R. Jia, P. S. Li, S. Q. Tu, Q. Zhu, W. Z. Tang, X. D. Li, Enzyme Microb. Technol., 2007, 2, 258-264.

[53] J. Jarvinen, S. Taskila, R. Isomaki, H. Ojamo, AMB Express, 2012, 2, 62, doi: 10.1186/2191-0855-2-62.

[54] R. S. Yehia, Braz. J. Microbiol., 2014, 45, 127-33.

\title{
从野生与突变株云芝 IBL-04 提纯锰过氧化物酶及其表征
}

\author{
Muhammad Asgher, Muhammad Ramzan, Muhammad Bilal* \\ 农业大学生物化学系工业生物技术实验室，费萨那巴德，巴基斯坦
}

摘要: 由野生及突变株云芝IBL-04制得细胞外锰过氧化物酶(MnPs), 并经过硫酸铵沉淀、透析、离子交换和凝胶渗透层析 法等步骤提纯. 纯化的酶在十二烷基硫酸钠-聚丙烯酰胺凝胶电泳(SDS-PAGE)上于 $43 \mathrm{kDa}$ 区域呈现单一谱带, 它适宜的 $\mathrm{pH}$ 值和温度分别为 5.0 和 $40^{\circ} \mathrm{C}$. 突变株 MnPs表现出比野生株MnPs更宽的活性pH值范围和更高的热稳定性. 从所选突变株所 得纯化的MnPs表现出与野生株MnP几乎相同的电泳性质、稳态动力学、金属离子和EDCs 降解效率. 该生物酶与 $\mathrm{Mn}^{2+}$ 一起 催化的反应速率最快, 但最高的亲和性对应于ABTS、甲氧基羟苯基乙二醇、4-氨基苯酚和活性染料. $\mathrm{Mn}^{2+}$ 和 $\mathrm{Cu}^{2+}$ 可显著提 高MnPs的活性, 但 $\mathrm{Zn}^{2+}, \mathrm{Fe}^{2+}, \mathrm{EDTA}$ 和半胱氨酸则会不同程度地抑制其活性, $\mathrm{Hg}^{2+}$ 是最强的活性抑制剂. 所有来源的MnPs 均可有效催化EDCs、壬基苯酚和二氯苯氧氯酚降解, 处理 $3 \mathrm{~h}$ 可除去 $80 \%$ 以上, 在MnPs-介质体系中可进一步提高到 $90 \%$. 综 上, 云芝MnPs生物酶具有较高的 $\mathrm{pH}$ 适用性和热稳定性、独特的Michaelis-Menten动力学参数和高的EDCs去除效率等特点, 因而有望工业化应用.

关键词：锰过氧化物酶；云芝IBL-04；提纯；表征；热稳定性；生物降解

收稿日期: 2015-11-08. 接受日期: 2016-01-14. 出版日期: 2016-04-05.

*通讯联系人. 电话: +92-41-9200161/3312; 电子信箱: bilaluaf@hotmail.com

本文的英文电子版由Elsevier出版社在ScienceDirect上出版(http://www.sciencedirect.com/science/journal/18722067). 